(052-057) Six proposals to amend Article 41.4 and to revise its Examples

Sennikov, Alexander N.

2015-06

Sennikov , A N 2015 , ' (052-057) Six proposals to amend Article 41.4 and to revise its

Examples ' , Taxon , vol. 64 , no. 3 , pp. 655-656 . https://doi.org/10.12705/643.32

http://hdl.handle.net/10138/156956

https://doi.org/10.12705/643.32

publishedVersion

Downloaded from Helda, University of Helsinki institutional repository.

This is an electronic reprint of the original article.

This reprint may differ from the original in pagination and typographic detail.

Please cite the original version. 


\title{
(052-057) Six proposals to amend Article 41.4 and to revise its Examples
}

\author{
Alexander N. Sennikov \\ Botanical Museum, Finnish Museum of Natural History, University of Helsinki, Unioninkatu 44, P.O. Box 7, 00014 Helsinki, Finland; \\ and Herbarium, Komarov Botanical Institute of Russian Academy of Sciences, Prof. Popov str. 2, 197376 St. Petersburg, Russia; \\ alexander.sennikov@helsinki.fi
}

DOI http://dx.doi.org/10.12705/643.32

(052) Revise Art. 41.4 as follows (new text in bold, deleted text in strikethrough):

"41.4. If, for a name of a genus or taxon of lower rank published before 1 January 1953, no reference to a basionym is given but the conditions for its valid publication as the name of a new taxon or replacement name are fulfilled, that name is nevertheless treated as a new combination or name at new rank when this was the author's presumed intent and a potential basionym (Art. 6.10) applying to the same taxon exists and there is no explicit evidence that the author's presumed intent was different."

The present Art. 41.4 in the Melbourne Code (McNeill \& al. in Regnum Veg. 154. 2012) is a direct descendant of the former Art. 33.3 in the Vienna Code (McNeill \& al. in Regnum Veg. 146. 2006). It was amended at the Melbourne Congress on the proposal by Turland (in Taxon 59: 1920. 2010). However, the final, published wording of the Article based on this proposal, intended to be "an editorial rewording of Art. 33.3 that did not really change the meaning" (Art. 33 Prop. G, Flann \& al. in PhytoKeys 41: 160. 2014), appeared to be quite distant from what was approved by the Congress. In my opinion, the Editorial Committee took the liberty of introducing a new condition into this Article, which made it depart from the original meaning.

The new wording of this Article states that it applies if publishing a new combination or a new replacement name "was the author's presumed intent". This condition, present neither in the former Art. 33.3 (“... if, for a presumed new combination ...") nor in Turland's proposal (“... if, for a presumed new combination or status novus at the rank of genus or below ...”), is a novelty.

It is often difficult to speculate about intentions of other authors, especially those who published in the remote past. Besides, the requirement "when this was the author's presumed intent" can hardly apply when there is "no reference" (Art. 41.4), not even an indirect or "cryptic" one (Art. 38.14), to the presumed new combination. If we can presume an intent, then we usually have at least an indirect or cryptic reference that serves as evidence of the intent; if we have no reference at all, then normally there is no evidence of such an intent, either.

To resolve this contradiction, I propose to modify Art. 41.4, using the mention of intent only as evidence to the contrary. Another goal of this proposal is to retain the applicability of this Article to the existing Examples under Art. 41.4, from which no evidence of the author's intent can be seen with certainty.

By this change, when no explicit intention of an author is evident (coinciding epithets disregarded), the cases will fall to the positive side of this rule, as originally implied by the wording "if ... no reference" in the previous versions of the Code before Melbourne. When original authors explicitly stated that they were describing new taxa without any connection to previous names (as "gen. nov.", "sp. nov.", "var. nov.", etc.), the cases will clearly fall to the negative side of Art. 41.4.

\section{(053) Add a new Example under Art. 41.4:}

"Ex. $n$. The new names Cyclachaena and Cyclachaena xanthiifolia were published by Fresenius (1836) with a description of the genus and no reference to the conspecific Iva xanthiifolia Nutt. (1818) which was originally collected in another place but along the same Missouri River. As Fresenius stated that he was describing a new genus ("nov. genus") and provided no separate description or diagnosis of its only species which was not necessarily new, his species name is treated as a new combination based on I. xanthiifolia because otherwise it would have been a name of new taxon published under Art. 38.5."

In this case, apparently the same, quite conspicuous species was named again but in another genus, without any reference to the previous publication. The distribution area indicated in both publications is narrow enough to be treated as the same, the diagnostic characters unmistakably point to the same species, and the fact that different collections were used by the two different authors does not exclude the possibility to treat the later name as based on the earlier one. Although Fresenius (Ind. Sem. Frankfort/M 1836: 1, 4. 1836) ascribed the species name Cyclachaena xanthiifolia to himself, he provided no evidence that he was describing a new species and not making a new combination with a basionym.

(054) Add another new Example under Art. 41.4:

"Ex. n. Sorbus franconica f. bakonyensis Jáv. (in Magyar Bot. Lapok. 25: 87. 1927) was raised to the rank of species by Jávorka (in Kert. Lapok 32: 284. 1928), who supplied a short diagnosis but provided no reference of any kind to the implied basionym. The identity of $S$. bakonyensis (Jáv.) Jáv. and $S$. franconica $\mathrm{f}$. bakonyensis is 
evident not only from the adopted epithet but also from the diagnostic characters, the first collector, and the distribution area, which coincide in both publications."

These two new Examples illustrate the situation where no reference to the applicable basionym of the new species name, not even an indirect or cryptic one, apparently exists, but the author provided no explicit evidence that his intention was to introduce the name of a new taxon (in its own right, as defined in Art. 6.9). Another example of the complete absence of any reference and apparent evidence of presumed intent is already in the Code, i.e., Ex. 9 on the case of Brachiolejeunea (Spruce) Steph. \& Spruce.

The example of Sorbus bakonyensis is borrowed from Somlyay \& Sennikov (in Phytotaxa 164: 265-275. 2014).

(055) Revise the current Ex. 7 under Art 41.4 as follows (new text in bold, deleted text in strikethrough):

"Ex. 7. Scaevola taccada was validly published by Roxburgh (1814) by a sole reference to an illustration in Rheede (Hort. Malab. 4: t. 59. 1683) that appears to be its sole basis is associated with a description of a species. As the name applies to the species previously described as Lobelia taccada Gaertn. (1788), it is treated as a new combination, S. taccada (Gaertn.) Roxb., not as the name of a new species, even though in Roxburgh's protologue there is no reference, either direct or indirect, to L. taccada."

These are plainly editorial adjustments to the wording of Ex. 7, in order to bring it closer to the original case. One may also think that a common element in the protologues of Lobelia taccada and Scaevola taccada, namely a reference to Rheede (Hort. Malab. 4: t. 59. 1683), may be treated as a kind of indirect reference to the presumed basionym in the same way as suggested in Ex. 5 under Art. 41.3 (Opuntia vulgaris Mill.), so that the concluding part of the Example ("there is no reference, either direct or indirect") seems to be doubtful.

(056) Add another new Example under Art. 41.4:

"Ex. $n$. The same taxon was described as Ruta perforata M. Bieb. (1800) and Haplophyllum perforatum Kar. \& Kir. (1841). In spite of the coinciding final epithets and inclusion of the presumably original locality of $R$. perforata in the protologue of $H$. perforatum, the latter name has no basionym because Karelin and Kirilov stated that they were describing a new species ("nov. sp.")."

This is an example when the same species was accidentally described twice with the same final epithet but under different generic names. As demonstrated by Linczevski (in Novosti Sist. Vyssh. Rast. [5]: 159-163. 1968), Bieberstein's publication was apparently neglected in subsequent research until the 20th century, and Karelin \& Kirilov (1841) compared their new species with H. acutifolium (DC.) G. Don, which was well known in the literature. The intention to describe a new species, explicitly expressed by Karelin \& Kirilov (1.c.), is against the provisions of Art. 41.4.

(057) Revise the current Ex. 10 under Art. 41.4 as follows and move it under Art. 38.14:

"Ex. [10]. Sampaio published "Psoroma murale Samp." (in Bol. Real Soc. Esp. Hist. Nat. 27: 142. 1927) with the only citation of "Lecanora saxicola Ach." in synonymy. By this citation he provided an indirect reference to the treatment of L. saxicola (Pollich) Ach. (Lichenogr. Universalis: 431. 1810), where the intended basionym Lichen muralis Schreb. (1771) is found in synonymy. The resulting name is to be cited as $P$. murale (Schreb.) Samp."

The present placement and wording of Ex. 10 are inappropriate because the work of Sampaio actually contains an indirect reference to Lichen muralis, the presumed basionym of Psoroma murale. Although this reference is more indirect than usual, it is still easy to trace and quite unambiguous.

\section{Acknowledgements}

I am grateful to Manuel B. Crespo (Universidad de Alicante) for raising the point and for the criticism of Art. 41.4 and its Examples, and to my colleagues at the Botanical Museum, University of Helsinki, for positive discussions about the subject of these proposals. Nicholas Turland (B) improved the text by editorial corrections and criticism. 